\title{
Occurrence, enterotoxin production and antimicrobic susceptibility of Staphylococcus aureus isolates from domestic cheeses
} in the Dubrovnik area

Ivana Ljevaković-Musladin*, Marina Vodnica-Martucci, Marija Krilanović and Lidija Kozačinski

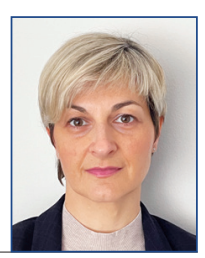

\section{Abstract}

Staphylococcus aureus is a well-known opportunistic pathogen that causes a wide range of acute and chronic diseases in both humans and animals. Staphylococcal food poisoning is just one of many diseases caused by this bacterium. The causative agents are enterotoxins produced by enterotoxigenic strains of $S$. aureus during its growth in favourable conditions in food. Epidemiological data show that $S$. aureus is often found in raw milk cheeses and accordingly, cheeses are often implicated in food poisoning outbreaks. Since there are no data on the nature of $S$. aureus isolated from cheese produced in Croatia, the aim of this study was to determine the occurrence, enterotoxin production capability and antimicrobic susceptibility of $S$. aureus isolates from domestic cheeses produced in the Dubrovnik area. A total of 30 cheese samples were analysed, and 18 samples $(60 \%)$ were highly contaminated with $S$. aureus strains. The contamination level ranged from 3.94 to $6.26 \log _{10} \mathrm{cfu} / \mathrm{g}$. Such a high level of contami- nation was supported by an inappropriate temperature regime above $8^{\circ} \mathrm{C}$ during market sale. Although highly contaminated, staphylococcal enterotoxins were not detected in any of the cheese samples. A total of 180 coagulase-positive isolates were collected from 18 cheese samples, 175 of which were confirmed as $S$. aureus by the latex agglutination test. Enterotoxin production was detected in 35 isolates $(20 \%)$, and of these 32 isolates produced staphylococcal enterotoxin C. The other three isolates presumably produced enterotoxin E. Antibiotic resistance was detected in $1.1 \%$ of isolates and only to mupirocin. However, a full comprehensive conclusion on the nature of $S$. aureus isolates cannot be achieved without determining its genotype characteristics for the presence of staphylococcal enterotoxin genes and molecular typing, to determine the origin of the isolates.

Key words: Staphylococcus aureus; cheese; staphylococcal enterotoxins; antimicrobial susceptibility

Ivana LJEVAKOVIĆ-MUSLADIN*, BSc Chem., Univ. Spec. Tech. Aliment., (Corresponding author, e-mail: ivana.ljevakovic-musladin@zzjzdnz.hr), Marina VODNICA-MARTUCCI, MD, Specialist in Medical Microbiology with Parasitology, Marija KRILANOVIĆ, MD, Clinical Microbiology Specialist, Institute of Public Health Dubrovnik, Dubrovnik, Croatia; Lidija KOZAČINSKI, DVM, PhD, Full Professor, Faculty of Veterinary Medicine, University of Zagreb, Zagreb, Croatia 


\section{Introduction}

Although it is a commensal bacterium, Staphylococcus aureus is a major opportunistic pathogen that under certain circumstances causes a wide range of acute and chronic diseases in both humans and animals. S. aureus causes an array of diseases, including: skin infections, pneumonia, toxic shock syndrome, staphylococcal food poisoning and hospital-acquired life-threatening sepsis in humans, as well as mastitis in dairy animals, joint and bone lesions in poultry, and skin infections in livestock. The pathogenicity of $S$. aureus is due to the vast spectrum of diverse virulence factors that this bacterium is able to produce. The already high pathogenicity is further dramatically enhanced by multiple resistances to a broad spectrum of antimicrobial drugs (Becker, 2018). $S$. aureus colonizes the human host and mammalian animals such as farm and companion animals. The nasal cavity is the main habitat of $S$. aureus, though skin, hair and mucous membranes in the throat, vaginal and gastrointestinal tract can also be colonized (Kluytmans et al., 1997). Nasal carriage of $S$. aureus plays an important role in staphylococcal diseases as a source and risk factor for subsequent infections (Wertheim et al., 2005).

Staphylococcal enterotoxins are low-molecular-weight (19-29 kDa), single-chain, globular proteins composed of approx. 168-261 amino acids (Balaban and Rasooly, 2000). Their crystal structures reveal significant homology in secondary and tertiary conformations (Mitchell et al., 2000). These toxins are produced by enterotoxigenic strains of $S$. aureus (not all strains are producers) during bacterial growth in favourable conditions in food. Many $S$. aureus strains can produce more than one type of enterotoxin (Hennekinne et al., 2012). Important characteristics of SEs are their remarkable resistance to heat, and their high stability and resistance to most proteolytic enzymes, which enables them to be biologically active in the digestive tract after ingestion (Le Loir et al., 2003). SEs are differentiated based on their antigenic properties, with 24 different types of SE and SE-like toxins (SEl) reported and described to date. The SE family now includes classical enterotoxins SEA to SEE, SEG to SET and staphylococcal enterotoxin-like U (SEIU) to SEIY (Fisher et al., 2018). Both SEs and SEls have superantigenic activity and belong to a large family of bacterial superantigen (Sag) exotoxins, as they bypass the normal immune response and induce a large proliferation of $\mathrm{T}$ cells, consequently resulting in pyrogenicity, enhancement of lethal endotoxin shock and a release of inflammatory cytokines (Argudin et al., 2010).

Staphylococcal food poisoning (SFP) is an intoxication caused by ingestion of food contaminated with a sufficient amount of staphylococcal enterotoxin(s). $S$. aureus is mainly introduced into food from food handlers either via respiratory droplets (if carriers) or via their contaminated hands or utensils (whether from carriers or cross-contamination). After ingestion, SEs very rapidly (within 2-8 h) induce symptoms of gastroenteric syndrome (nausea, emesis, abdominal cramps and diarrhoea) in humans. The disease is usually self-limiting and typically resolves within $24-48 \mathrm{~h}$ after onset (Le Loir et al., 2003). Toxic dose is very low, $20 \mathrm{ng}$ to $<1 \mu \mathrm{g}$ (Normanno et al., 2007a). SFP is a common disease whose real incidence is probably underestimated due to misdiagnosis, unreported minor outbreaks, improper sample collection and improper laboratory examination. SFP was the second most reported type of food-borne disease in France (Kérouanton et al., 2007). About 95\% of staphylococcal food poisoning is caused by the classical enterotoxins A, B, C, D and E (Pelisser et al., 2009), with SEA as the most common 
enterotoxin implicated in food poisoning outbreaks (Balaban and Rasooly, 2000; Hennekinne et al., 2012). Wieneke at al. (1993) reported that $50 \%$ of SFP in the United Kingdom was caused by SEA. SEA is mostly produced by human strains, while animal strains isolated from cow's milk are mostly SEC and SED producers (EC Opinion, 2003). According to the 2018 EFSA/CDC zoonoses report, there were 114 SFP outbreaks in the EU with 1,124 human cases, mostly caused by mixed food, cereal products (including rice) and cheese. However, data on the nature of the enterotoxin were not published. The same paper reported that $S$. aureus was found in cheeses made from cow's milk, goat's milk, mixed milk (cows, sheep and/ or goats) and unspecified or other animal milk, among other foods. Meanwhile SEs were detected mostly in milk and dairy products (EFSA/CDC, 2019). De Buyser et al. (2001) reported that $S$. aureus was also the most frequent pathogen associated with cheeses in food-borne disease outbreaks in France in 1992-1997, where there is a very long and prominent tradition of eating raw milk cheeses.

$S$. aureus is the most common cause of mastitis in dairy animals. Direct excretion from the cow's clinical or subclinical mastitic udder leads to milk contamination. Unhygienic handling during cheeseproduction, includingfaecal contamination of milk, contamination of the milking equipment or contamination by the producer themselves, also induces $S$. aureus into milk and/or cheese (Little et al., 2008). A study conducted by Rola et al. (2016) showed that a lower number of $S$. aureus in cheeses is obtained by both good microbiological quality of milk and negative findings of coagulase-positive staphylococci on the hands of the cheese makers (Rola et al., 2016).

Food is also an important vehicle for the transfer of antimicrobic resistance. Both animals and humans can be carriers of resistant strains, thus introducing antimicrobial resistance into the food chain. MRSA strains have been detected in different foods, including bovine milk and cheese (Normanno et al., 2007a). Kerouanton et al. (2007) reported two MRSA strains of the 33 tested from SFP outbreaks. Since $S$. aureus is a common causative agent of mastitis in dairy cows, resistance to certain antibiotics can be expected, as can the presence of resistant strains in dairy products.

Previous studies conducted by the Institute of Public Health in Dubrovnik, Croatia showed that 66 to $70 \%$ of domestic cheeses from the Dubrovnik area were highly contaminated with coagulasepositive staphylococci, predominantly $S$. aureus (Ljevaković-Musladin et al., 2014; Ljevaković-Musladin et al., 2016). Currently there are no data on the nature of $S$. aureus isolates from cheese produced in the Dubrovnik area, nor on their enterotoxigenic potential and antimicrobic resistance.

Considering the above, the aims of this study were to determine the i) occurrence, ii) enterotoxin production capability, and iii) antimicrobic susceptibility of $S$. aureus isolates from domestic cheeses produced in the Dubrovnik area.

\section{Materials and methods}

Cheese samples. A total of 30 bovine and caprine milk cheese samples were collected from Dubrovnik city markets during 2018 and 2019. Cheeses were produced by 17 small-scale, unregistered, domestic producers or small family farms, with a production capacity of 1.5-4 $\mathrm{kg}$ of cheese per week and 1-2 cows and/ or goats. No samples were refrigerated during sale at the market and many were exposed to direct sunlight during the warm months, being sold on a stand. The temperature of samples was immediately measured by probe thermometer (at depth in middle of the sample). After collection, samples were transported 
to the laboratory in a cooling box for approximately 20 minutes.

Microbiological analyses. All cheese samples were analysed according to HRN EN ISO 6888-1:2004 using Baird-Parker agar for the enumeration of coagulase-positive staphylococci (CM1127, Oxoid, Basingstoke, UK). Colonies were identified as $S$. aureus based on the coagulase and catalase test, Gram staining, Dnase test and latex agglutination for detection of fibrinogen affinity antigen (clumping factor), protein $\mathrm{A}$ and capsular polysaccharides of $S$. aureus. Ten coagulase-positive colonies per sample were used in further examination.

Bacterial strains. In total, 180 isolates were collected from 18 samples, and 12 of 30 samples were not contaminated with S. aureus. All coagulase-positive isolates were tested for enterotoxin production and antibiotic susceptibility.

Gram staining. Gram staining was conducted according to the American Society for Microbiology protocol, with crystal violet, iodine and safranin dyes. Gram-positive (dark purple) cocci in clusters were considered Staphylococcus strains.

Coagulase test. Production of free coagulase enzyme was tested by the tube method according to HRN EN ISO 68881:2004. A representative individual colony (black colony with an opaque halo) from the Baird-Parker agar was inoculated in a Brain Heart Infusion broth (CM1135, Oxoid, Basingstoke, UK) incubated at $37^{\circ} \mathrm{C}$. An overnight culture $(0.1 \mathrm{~mL})$ from the Brain Heart Infusion broth was added to $0.3 \mathrm{~mL}$ Bactident ${ }^{\circledR}$ Coagulase plasma EDTA (Merck, Darmstadt, Germany). Tubes were incubated at $37^{\circ} \mathrm{C}$ for $4-24$ h. Clot formation (2/3 of volume) was considered a positive coagulase test.

Dnase test. A representative single colony (black colony with an opaque halo) from the Baird-Parker agar plate was streaked in a single line on a Dnase agar plate (CM0321, Oxoid, Basingstoke, UK) and incubated at $37^{\circ} \mathrm{C}$. After $24 \mathrm{~h}$, the incubation plate was flooded with $1 \mathrm{M}$ hydrochloric acid $(\mathrm{HCl})$. A clear zone around the growth line indicated a positive reaction.

Catalase test. Catalase enzyme detection was performed by the drop method. A well-isolated representative colony from the Baird-Parker agar was placed onto the microscope slide and flooded with one drop of 3\% hydrogen peroxide $\left(\mathrm{H}_{2} \mathrm{O}_{2}\right)$. An immediate bubble formation was considered positive reaction.

Latex agglutination test. Each coagulase-positive colony was subjected to the Pastorex ${ }^{\mathrm{TM}}$ Staph Plus test (ref. 56356, Bio-rad, Marnes-la-Coquette, France). The test was conducted according to the manufacturer's instructions. Colonies which gave a positive result (formation of aggregates) were confirmed as Staphylococcus aureus.

Enterotoxin detection in cheese samples. It was conducted by an immunoenzymatic detection of staphylococcal enterotoxins according to HRN EN ISO 19020:2017, which included extraction followed by a concentration based on dialysis principle, and an immunoenzymatic detection using VIDAS $^{\text {TM }}$ SET2 method (ref. 30705, bioMerieux, Marcy-l'Etoile, France).

Enterotoxin production. All isolates were examined for the production of A, B, C, D and E enterotoxins by two immunoassay methods: the automated VIDAS $^{\text {TM }}$ SET2 method (ref. 30705, bioMerieux, Marcy-l'Etoile, France) and Reverse Passive Latex Agglutination method (SET-RPLA Toxin Detection Kit, TD0900A, Thermo Scientific ${ }^{\mathrm{TM}}$ Oxoid $^{\mathrm{TM}}$, Basingstoke, UK). Wellisolated colonies from the Baird-Parker agar were inoculated in Tryptone Soya broth (CM 129, Oxoid, Basingstoke, $\mathrm{UK}$ ) and incubated at $37^{\circ} \mathrm{C} / 18-24 \mathrm{~h}$. After incubation, $1 \mathrm{~mL}$ culture was 
centrifuged at $900 \times \mathrm{g}$ for 20 minutes and the supernatant was used for further analyses. Then $500 \mu \mathrm{L}$ supernatant was tested with the VIDAS ${ }^{\text {TM }}$ SET2 method while the other $25 \mu \mathrm{L}$ supernatant was tested with an RPLA kit, both following the manufacturer's instructions. VIDAS ${ }^{\mathrm{TM}}$ SET2 interpreted results as positive/ negative for enterotoxin detection, according to a quantitative comparison with standard and positive control. VIDAS $^{\text {TM }}$ SET2 was used to detect the production of SEA-SEE enterotoxins without distinguishing individual toxins. In the RPLA test, according to the manufacturer's instructions, the following agglutination reactions are considered positive: complete agglutination, moderate agglutination and a small pellet visible in the centre of the agglutinated latex. RPLA was used in order to distinguish which enterotoxin (SEA, SEB, SEC or SED) was produced.

Antibiotic susceptibility testing. This was conducted using the EUCAST disk diffusion method on Mueller-Hinton agar (CM0337, Oxoid, Basingstoke, UK). A pure culture from Columbia blood agar was suspended in sterile saline $(0.85 \% \mathrm{NaCl} \mathrm{w} / \mathrm{v}$ in water) to the density of a 0.5 McFarland standard (photometric measurement on the Biosan DEN-1B densimeter). The suspension was evenly inoculated on a MuellerHinton agar. Seven antibiotic discs were applied on a $90-\mathrm{mm}$ plate within 15 minutes of inoculation. Antibiotic discs are listed as follows (antibiotic concentration in $\mu \mathrm{g}$ ): azithromycin (15), cefoxitin (30), clindamicin (2), erythromycin (15), gentamicin (10), moxifloxacin (5), mupirocin (5), oxacilin (5) and trimethoprim-sulphamethoxazole (1.25/23.75), all from Biorad, Marnesla-Coquette, France. The plates were incubated inverted at $35 \pm 1^{\circ} \mathrm{C} / 16-20 \mathrm{~h}$. After incubation, inhibition zones were read to the point where there was no growth by ruler. The interpretation of the results was conducted according to the EUCAST manual and criteria.

Statistical analysis. Descriptive statistics were used to calculate the average value, minimum, maximum and range. A chi-square test at significance level of 0.05 was used to determine the statistical significance of difference between separate data sets.

\section{Results}

Of the 30 analysed cheese samples, 18 samples $(60 \%)$ were highly contaminated with $S$. aureus strains. The contamination level ranged from 3.94 to $6.26 \log _{10} \mathrm{cfu} / \mathrm{g}$, with an average value of $5.43 \log _{10} \mathrm{cfu} / \mathrm{g}$ (Table 1). The temperature of cheese samples measured immediately after purchase ranged between 6 and $23.3^{\circ} \mathrm{C}$, with an average value of $12.5^{\circ} \mathrm{C}$. Cheese production was based mostly on the mild heating of milk (sub-pasteurization temperature) and coagulation using apple cider vinegar or domestic veal rennet.

A total of 180 isolates were collected from 18 positive cheese samples. Following confirmatory tests, 175 coagulase-positive isolates showing a positive latex agglutination reaction were confirmed as $S$. aureus.

Enterotoxins were not detected in any of the cheese samples positive for S. aureus. The results of enterotoxin production in isolates are shown in Table 2. The VIDAS $^{\circledR}$ method detected enterotoxin production in 35 of 175 tested isolates, while the RPLA method confirmed enterotoxin $\mathrm{C}$ production in 32 positive strains.

All 175 isolates were subjected to antimicrobial susceptibility testing for the following antibiotics: azithromycin, cefoxitin, clindamycin, erythromycin, gentamicin, moxifloxacin, mupirocin, oxacillin and trimethoprimsulphamethoxazole. Only two (1.1\%) isolates from the same sample were 
Table 1. Characteristics of domestic cheese collected from Dubrovnik city markets

\begin{tabular}{|c|c|c|c|c|}
\hline Sample & $\begin{array}{l}\text { Producer (P)/ } \\
\text { Milk type }\end{array}$ & $\begin{array}{c}\text { Temperature }\left({ }^{\circ} \mathrm{C} \text { ) }\right. \\
\text { (in cheese) }\end{array}$ & $\begin{array}{l}\text { S. aureus } \\
\left(\log _{10} \mathrm{cfu} / \mathrm{g}\right)\end{array}$ & SE* detection \\
\hline S1 & P1/Cow milk & 7.3 & 4.11 & Negative \\
\hline S2 & P1/Cow milk & 7.6 & 4.04 & Negative \\
\hline S3 & P2/Cow milk & 13.0 & 6.26 & Negative \\
\hline S4 & P3/Cow milk & 11.9 & 6.15 & Negative \\
\hline S5 & P4/Cow milk & 11.8 & $<1$ & NE \\
\hline S6 & P4/Goat milk & 11.9 & $<1$ & NE \\
\hline S7 & P5/Cow milk & 22.0 & $<1$ & NE \\
\hline S8 & P6/Cow milk & 13.1 & 6.04 & Negative \\
\hline s9 & P2/Cow/goat milk & 19.8 & $<1$ & NE \\
\hline $\mathrm{S} 10$ & P3/Cow milk & 23.1 & $<1$ & NE \\
\hline S11 & P7/Goat milk & 6.8 & 5.18 & Negative \\
\hline $\mathrm{S} 12$ & P6/Cow milk & 13.3 & 5.36 & Negative \\
\hline $\mathrm{S} 13$ & P8/Cow milk & 8.4 & 3.94 & Negative \\
\hline $\mathrm{S} 14$ & P9/Cow milk & 8.5 & 5.40 & Negative \\
\hline S15 & P10/Cow milk & 12.4 & 6.0 & Negative \\
\hline $\mathrm{S} 16$ & P1/Cow milk & 7.4 & 6.0 & Negative \\
\hline $\mathrm{S} 17$ & P7/Cow/goat milk & 14.2 & 4.78 & Negative \\
\hline $\mathrm{S} 18$ & P11/Cow milk & 10.0 & $<1$ & NE \\
\hline $\mathrm{S} 19$ & P12/Cow milk & 6.5 & $<1$ & NE \\
\hline $\mathrm{S} 20$ & P10/Cow milk & 6.0 & $<1$ & NE \\
\hline $\mathrm{S} 21$ & P9/Cow milk & 8.4 & 5.79 & Negative \\
\hline $\mathrm{S} 22$ & P1/Cow milk & 23.3 & 6.26 & Negative \\
\hline $\mathrm{S} 23$ & P1/Cow milk & 21.8 & 6.15 & Negative \\
\hline S24 & P13/Cow milk & 17.5 & $<1$ & NE \\
\hline $\mathrm{S} 25$ & P14/Cow milk & 12.9 & $<1$ & NE \\
\hline $\mathrm{S} 26$ & P15/Cow milk & 7.4 & $<1$ & NE \\
\hline $\mathrm{S} 27$ & P15/Cow milk & 6.2 & $<1$ & NE \\
\hline $\mathrm{S} 28$ & P16 /Cow milk & 12.7 & 5.45 & Negative \\
\hline $\mathrm{S} 29$ & P17 / Cow milk & 13.8 & 6.08 & Negative \\
\hline $\mathrm{S} 30$ & P17 /Cow milk & 17.3 & 4.85 & Negative \\
\hline
\end{tabular}

* SE $=$ staphylococcal enterotoxins

$\mathrm{NE}=$ not examined 
Table 2. Enterotoxin production in S. aureus isolates from cheese samples

\begin{tabular}{|c|c|c|c|}
\hline \multirow{2}{*}{$\begin{array}{c}\text { Cheese sample/ } \\
\text { Producer }\end{array}$} & \multirow{2}{*}{$\begin{array}{l}\text { No. of } \\
\text { isolates }\end{array}$} & $\begin{array}{l}\text { SE production } \\
\text { (VIDAS }{ }^{\circledR} \text { SET2) } \\
\end{array}$ & $\begin{array}{c}\text { Staphylococcal } \\
\text { Enterotoxin (RPLA) }\end{array}$ \\
\hline & & No. of positive isolates & No. of positive isolates \\
\hline $\mathrm{S} 1 / \mathrm{P} 1$ & 7 & 5 & 5; SEC \\
\hline $\mathrm{S} 2 / \mathrm{P} 1$ & 9 & 7 & 7; SEC \\
\hline $\mathrm{S} 3 / \mathrm{P} 2$ & 10 & 0 & 0 \\
\hline S4/P3 & 10 & 0 & 0 \\
\hline S8/P6 & 10 & 0 & 0 \\
\hline S11/P7 & 10 & 0 & 0 \\
\hline S12/P6 & 10 & 0 & 0 \\
\hline S13/P8 & 10 & 0 & 0 \\
\hline S14/P9 & 10 & 7 & 7; SEC \\
\hline S15/P10 & 9 & 3 & 0 \\
\hline S16/P1 & 10 & 8 & 8; SEC \\
\hline S17/P7 & 10 & 0 & 0 \\
\hline S21/Pq & 10 & 1 & 1; SEC \\
\hline S22/P1 & 10 & 1 & 1; SEC \\
\hline S23/P1 & 10 & 3 & 3; SEC \\
\hline $\mathrm{S} 28 / \mathrm{P} 16$ & 10 & 0 & 0 \\
\hline S29/P17 & 10 & 0 & 0 \\
\hline S30/P17 & 10 & 0 & 0 \\
\hline Total: & 175 & 35 & 32 \\
\hline
\end{tabular}

resistant, and only to mupirocin, while all other isolates $(98.9 \%)$ were sensitive to all antibiotics tested.

\section{Discussion}

Since there were previously no data on the microbiological quality of domestic cheeses sold at Dubrovnik city markets, the Institute of Public Health Dubrovnik conducted its first screening in 2014. The collected data showed very poor microbiological quality, with 24 of 30 cheese samples $(80 \%)$ of unsatisfactory quality due to a high level of $S$. aureus and/or E. coli contamination, including $S$. aureus in 20 samples (66\%) (Ljevaković-
Musladin et al., 2014). Screening was repeated in 2015 with an almost identical outcome: S. aureus contamination was found in 22 out of 30 samples (73\%) (Ljevaković-Musladin et al., 2016). Neither of these screenings included research on enterotoxin production or antibiotic resistance, which is why the present study was designed to determine phenotypic characteristics with regards to enterotoxin production and antimicrobic susceptibility of $S$. aureus isolates from domestic cheeses produced in the Dubrovnik area.

The findings of the present study are identical to the results of the previous screenings, showing no improvement 
in microbiological quality. There is also no statistically significant difference between the data of all three screenings (chi square $=3.0288, P=0.219935, P<0.05$ ). However, these findings significantly differ from those reported by the Croatian Food Agency in 2014, whose purpose was to gain insight into the microbiological quality of traditionally produced cheeses sold at markets in major Croatian cities (Zagreb, Rijeka, Split and Osijek). Those results showed a very low level of $S$. aureus contamination. The average contamination of fresh cheese with $S$. aureus was $1.21 \times 10^{1} \mathrm{cfu} / \mathrm{g}$ and contamination prevalence was $13.46 \%$. The research concluded that there is a low risk associated with the presence of $S$. aureus in traditionally produced fresh cheeses (Croatian Food Agency, 2016). Some other studies in Croatia showed variable results. Samaržija et al. (2007) found that $13 \%$ of traditional hard sheep cheeses made of raw milk from the island of Pag and 7\% of Istrian cheeses contained $S$. aureus at a level higher than $10^{4} \mathrm{cfu} / \mathrm{g}$. Research by Markov et al. (2009) showed that only 10 of 66 (16.66\%) samples of fresh cheese and cream of domestic production from the Zagreb city area were contaminated with $S$. aureus, ranging from $5.2 \times 10^{2}$ to $2.3 \times 10^{3} \mathrm{cfu} / \mathrm{g}$. The latest study by Frece et al. (2016) found that two thirds of 39 samples of milk, curd and cheese had higher counts of staphylococci (and enterobacteria) than permitted by the regulations, ranging from $1.9 \log _{10} \mathrm{cfu} / \mathrm{g}$ to $6.3 \log _{10} \mathrm{cfu} / \mathrm{g}$. Although highly contaminated, only two cheese samples contained enterotoxin C. A recent study by Landeka et al. (2019) investigated the microbiological quality of fresh cow's milk cheese sold at Sarajevo and Zagreb farmers' markets. The average amount of $S$. aureus in fresh cheese samples collected in Zagreb was $1.13 \pm 1.37 \log _{10} \mathrm{cfu} / \mathrm{g}$, while the average amount found in Sarajevo was $1.94 \pm 1.59$ $\log _{10} \mathrm{cfu} / \mathrm{g}$. By comparison we concluded that the poor microbiological quality of domestic cheeses in the Dubrovnik area is the result of a significant lack of good hygiene practice during cheese production and storage, and a lack of education and awareness about the health risks related to unhygienic cheese production. Lack of sanitary control and surveillance of sales at markets also plays a crucial role.

S. aureus was also the most frequent cheese contaminant in other international studies. In their survey of retail cheeses in the UK, Little et al. (2008) found a $30 \%$ prevalence of $S$. aureus in raw milk cheeses, with enterotoxigenic populations frequently exceeding the EU recommendations. A Brazilian study of traditional Canastra cheese by Borelli et al. (2006) showed a highlevel contamination with S. aureus; $70 \%$ of cheese samples were contaminated with population counts up to $6.3 \log _{10}$ $\mathrm{cfu} / \mathrm{g}$. In Scotland, S. aureus was the most frequently detected foodborne pathogen in a survey of farmhouse cheeses, detected in $40 \%$ of samples (Williams and Withers, 2010). A study in Sweden by Rosengren et al. (2010) reported that $S$. aureus was detected in $69 \%$ of raw milk cheeses and $6 \%$ of cheeses made from pasteurized milk. Rola et al. (2016) reported that $69.2 \%$ of cheeses from small scale production in Poland were contaminated with $S$. aureus with up to $7.41 \log _{10} \mathrm{cfu} / \mathrm{g}$. On the other hand, a study in the USA by Brooks et al. (2012) reported a very low prevalence of $S$. aureus in raw milk cheeses. Only three of 41 analysed samples had a detectable level of $S$. aureus, which is probably due to US regulations according to which sales and distribution of raw milk is not allowed, and cheese production from unpasteurized milk is permitted only if the cheese has been aged according to federal guidelines (Brooks et al., 2012).

According to the EU legislation (Regulation No. 2073/2005), all samples with a level of $S$. aureus $>10^{5} \mathrm{cfu} / \mathrm{g}$ 
must be examined for the presence of staphylococcal enterotoxins. These levels of $S$. aureus produce detectable amounts of SE and pose a significant risk, since the infectious dose of SE is rapidly achieved (EC, 2003). Although the number of $S$. aureus in most cheeses reduces over time, once the enterotoxins are produced their concentration remains the same with the possibility of causing illness. None of the cheese samples tested in the present study, even those with high levels of $S$. aureus, contained SEs. This finding is consistent with other studies (Cremonesi et al., 2007; Little et al., 2008; O'Brien et al., 2009; Rosengren et al, 2010; Rola et al, 2016), as SEs are rarely routinely found in cheese. According to the 2018 EFSA Zoonoses Report, SEs were found in only four cheese samples of the total 815 tested $(0.25 \%)$. They are mostly found in staphylococcal food poisoning investigations (Hennekinne et al., 2012; Kadariya et al., 2014). However, these studies have shown that although SEs were absent in cheeses, S. aureus isolates were able to produce enterotoxin(s) and possessed one or more se genes.

The present study showed that 8 of 30 cheese samples $(26.7 \%)$ contained a mixture of SE positive and SE negative $S$. aureus strains, highlighting the heterogeneous nature of $S$. aureus population within a single sample. This finding is in agreement with the study by Loncarevic et al. (2005), which revealed considerable diversity of $S$. aureus isolates both among samples and within a single sample. The same study recommended testing up to 10 colonies to increase the chance of identifying a potential source of staphylococcal intoxication. Cheese samples from the present study which were contaminated with enterotoxinproducing isolates were prepared by the same two cheese makers, and their presence was detected in several sampling rounds. This finding implies the need for more frequent samplings of the same producers in order to determine the enterotoxigenic potential of $S$. aureus in cheese.

Of the $175 \mathrm{~S}$. aureus isolates in the present study, $35(20.0 \%)$ were SE producers detected by the VIDAS method and $32(18.3 \%)$ were enterotoxin C producers detected by the RPLA method. No other toxins were detected. There are two possible reasons for the discrepancy of results between the VIDAS ${ }^{\circledR}$ and RPLA methods. The isolates not detected by RPLA could eventually be enterotoxin SEE producers since the RPLA kit cannot detect this enterotoxin, or they could be VIDAS false positives. The results of enterotoxin production in isolates are in agreement with studies from Spain, Switzerland, Norway, Japan, Brazil, Italy and Ireland, where SEC enterotoxin is most frequently produced by cow and goat strains and found in cow and goat milk and raw milk cheeses (Fueyo et al., 2001; Stephen et al., 2001; Loncarevic et al., 2005; Jørgensen et al., 2005; Katsuda et al., 2005; da Silva et al., 2005; Cremonesi et al., 2007; Hunt et al., 2012). It has also been recognised that SEC-producing $S$. aureus are generally associated with dairy products (Tamarapu et al., 2001). A German study by Akineden et al. (2008) showed that $S$. aureus strains from goat's milk cheeses were SEA or SEC producers, where SEA producers were mostly of human origin and the SEC producers were of animal origin. According to Jørgensen et al. (2005) S. aureus isolates proved to be genetically diverse and certain genotypes appeared to be source-specific. A French study on enterotoxigenic $S$. aureus strains collected from different foodstuffs by Rosec et al. (1997) found that they were mostly of human biovar origin, which confirms that humans are the main source of food contamination. That study also reported that SEC was the predominant type in both foodstuffs and human isolates, representative of the geographical area of 
production and sampling. A later study by De Buyser et al. (2001) reported SEA as the dominant type of enterotoxin produced by human isolates and the most frequent cause of SFP in France. Pinchuk et al. (2010) considered SEC toxin least important since it is rarely implicated in staphylococcal food poisoning. To our knowledge, there have been no such cases of SFP in our county of reference associated with the consumption of either domestic cheeses or staphylococcal enterotoxin C.

Many otherstudieshavereported more complex and diverse results than ours, and there is a great discrepancy in the data concerning prevalence of enterotoxigenic $S$. aureus strains. According to Fueyo et al. (2001) enterotoxin prevalence is probably affected by the origin of the strain (human, animal or food) and the number and types of samples examined. Enterotoxin A, B and C producers are frequently reported in Brazilian cheese (Carmo et al., 2002; Borelli et al., 2006). A high frequency of SEA, SED and SEC producers respectively was found in raw milk and dairy products in Italy (Morandi et al., 2009). On the other hand, Ertas et al. (2010) reported a very low frequency of SEA-SED producers from sheep's cheese. Several authors presumed a regional distribution of different SE genotypes (Rosec et al., 1997; Stephen et al., 2001; Rola et al., 2016).

In addition to enterotoxigenicity, considerable risk of $S$. aureus strains in cheese and food in general comes from antimicrobic resistance. Contrary to expectations, detected antimicrobic resistance was extremely low and limited to mupirocin, which is commonly used in the treatment of skin infections and nasal decolonization of $S$. aureus (Patel et al., 2009). Hence, it can be concluded that there was not an (over)consumption of antibiotics in animal treatment. Currently there are no published data on antimicrobic resistance of $S$. aureus isolates from cheese in Croatia. A study by Zdolec et al. (2016) investigated antimicrobial susceptibility of raw milk bacteria, including staphylococci, and reported that resistant staphylococci were found in milk samples from healthy udders, with the most common resistance to penicillin, erythromycin and kanamycin. On the other hand, staphylococci isolated from drug-treated udder milk samples were most frequently resistant to clindamycin, penicillin, ampicillin, linezolid and erythromycin (Zdolec et al., 2016).

Our results are in disagreement with other studies where antimicrobic resistance ranged from low (Stephen et al., 2001) to remarkable (Normanno et al., 2007a; Kerouanton et al., 2007; Rola et al., 2016). Normanno et al. (2007b) even isolated MRSA strains from cow's milk and cheese, and all MRSA strains were able to synthesize enterotoxins, mostly SEA, SED and SEC. The same authors suggested that food can be an appropriate environment for the spread of antimicrobial resistance throughout the food chain, and between the environment and humans.

\section{Conclusions}

Domestic cheese produced in Dubrovnik area is highly contaminated with $S$. aureus as a result of inappropriate hygiene during production, and an inappropriate temperature regime during market sales and possibly during storage. Although highly contaminated, staphylococcal enterotoxins were not detected in any of the cheese samples. This is mainly due to the fact that most $S$. aureus isolates in this study were not enterotoxin producers. Enterotoxin producing S. aureus was found in 8 of 30 cheese samples, and those samples came from the same two cheese manufacturers. The only SEC production was detected in $S$. aureus isolates and we presume those isolates are of animal origin, 
although there is also a possibility that they came from a human source. Antibiotic resistance was not detected since the isolates were susceptible to all antibiotics tested. However, a full comprehensive conclusion on the nature of $S$. aureus isolates cannot be achieved without determining their genotype characteristics regarding the presence of staphylococcal enterotoxin genes, and molecular typing with the purpose of determining the origin of isolates. Education of cheese manufacturers about good hygiene practice, refrigeration of cheese during market sales, along with sanitary control and surveillance, could significantly improve the microbiological quality and safety of cheese produced in the Dubrovnik area.

\section{Acknowledgment}

We would like to express our gratitude to the Microbiology Department staff at the Public Health Institute Dubrovnik, especially to Mrs. Luce Njirić for providing technical help in conducting the Antibiotic susceptibility testing.

\section{References}

1. AKINEDEN, Ö., A. A. HASSAN, E. SCHNEIDER and E. USLEBEER (2008): Enterotoxigenic properties of Staphylococcus aureus isolated from goat's milk cheese. Int. J. Food Microbiol. 124, 211-216.

2. ARGUDÍN, M. A., M. C. MENDOZA and M. R. RODISIO (2010): Food Poisoning and Staphylococcus aureus Enterotoxins. Toxins 2, 1751-1773.

3. BALABAN, N. and A. RASOOLY (2000): Staphylococcal enterotoxins. Int. J. Food Microbiol. 61, 1-10.

4. BECKER, K. (2018): Pathogenesis of Staphylococcus aures. In: Fetsch, A.: Staphylococcus aureus. London, United Kingdom (13-38).

5. BORELLI, B.M., E.G. FERREIRA, I.C. A. LACERDA, D. A. SANTOS, L. S. CARMO, R. S. DIAS and M. C. C. SILVA (2006): Enteroxigenic Staphylococcus spp. and other microbial contaminants during production of Canastra cheese, Brazil. Braz. J. Microbiol. 37, 545-550.

6. BROOKS, J. C., B. MARTINEZ, J. STRATTON, A. BIANCHINI, R. KROKSTROMB and R. HUTKINS (2012): Survey of raw milk cheeses for microbiological quality and prevalence of foodborne pathogens. Food Microbiol. 31, 154-158.

7. CARMO, L. S., R. S. DIAS, V. R. LINARDI, M. J. SENA, D. A. SANTOS, E. FARIA, E. C. PENA, M.
JETT and L. G. HENEINE (2002): Food poisoning due to enterotoxigenic strains of Staphylococcus present in Minas cheese and raw milk in Brazil. Food Microbiol. 19, 9-14.

8. CREMONESI, P., G. PEREZ, G. PISONI, P. MORONI, S. MORANDI, M. LUZZANA, M. BRASCA and B. CASTIGLIONI (2007): Detection of enterotoxigenic Staphylococcus aureus isolates in raw milk cheese. Lett. Appl. Microbiol. 45, 586-591.

9. CROATIAN FOOD AGENCY (2016): Scientific opinion on microbiological hazards in fresh and semi-soft cheeses at Croatian markets and their chemical parameters. Available at: https:// www.hah.hr/wp-content/uploads/2015/10/ZMo-mikrobioloskim-opasnostima-u-svjezim-ipolutvrdim-sirevima.pdf (accessed 02 April 2021).

10. DA SILVA, E. R., L.S. DO CARMO and N. DA SILVA (2005): Detection of the enterotoxins A, B, and $\mathrm{C}$ genes in Staphylococcus aureus from goat and bovine mastitis in Brazilian dairy herds. Vet. Microbiol. 106, 103-107.

11. DE BUYSER, M. L., B. DUFOUR, M. MAIRE and V. LAFARGE (2001): Implication of milk and milk products in food-borne diseases in France and in different industrialised countries. Int. J. Food Microbiol. 67, 1-17.

12. ERTAS, N., Z. GONULALAN, Y. YILDIRIM and E. KUM (2010): Detection of Staphylococcus aureus enterotoxins in sheep cheese and dairy desserts by multiplex PCR technique. Int. J. Food Microbiol. $142,74-77$.

13. EC - EUROPEAN COMMISSION (2003): Opinion on Staphylococcal Enterotoxins in milk products, particularly cheeses. Available online: https:// ec.europa.eu/food/sites/food/files/safety/docs/sci-com_ scv_out61_en.pdf (accessed on 15 November 2020).

14. EC-EUROPEANCOMMISSION(2005):Commission Regulation (EC) No 2073/2005 of 15 November 2005 on microbiological criteria for foodstuffs. Available online: https://eur-lex.europa.eu/legal-content/EN/ TXT/?uri=CELEX:02005R2073-20140601 (accessed on 15 November 2020).

15. EFSA and ECDC (European Food Safety Authority and European Centre for Disease Prevention and Control) (2019): The European Union One Health 2018 Zoonoses Report. EFSA Journal 17(12):5926, 276 pp.

16. EUCAST Disk Diffusion Method for Antimicrobial Susceptibility Testing Manual Version 9.0 (January 2021). Available at: https://www.eucast.org/ast_of_ bacteria/disk_diffusion_methodology/ (accessed 02 April 2021).

17. EUCAST Disk Diffusion Method for Antimicrobial Susceptibility Testing Reading Guide Version 8.0 (January 2021). Available at: https://www.eucast. org/ast_of_bacteria/disk_diffusion_methodology/ (accessed 05 April 2021).

18. FISHER, E. L., M. OTTO and G. Y. C. CHEUNG (2018): Basis of Virulence in Enterotoxin-Mediated Staphylococcal Food Poisoning. Front. Microbiol. 9, 436.

19. FRECE, J., M. VRDOLJAK, M. FILIPČIĆ, M. JELIĆ, I. ČANAK, Ž. JAKOPOVIĆ, J. PLEADIN, I. GOBIN, LANDEKA T. DRAGIČEVIĆ and K. MARKOV (2016): Microbiological Quality and Variability of Natural 
Microbiota in Croatian Cheese Maturing in Lambskin Sacks. Food Technol. Biotechnol. 54, 129-134.

20. FUEYO, J. M., M. C. MARTÍN, M. A. GONZÁLEZHEVIA and M. C. MENDOZA (2001): Enterotoxin production and DNA fingerprinting in Staphylococcus aureus isolated from human and food samples: Relations between genetic types and enterotoxins. Int. J. Food Microbiol. 67, 139-145.

21. HENNEKINNE, J.-A., M. L. DE BUYSER and S. DRAGACCI (2012): Staphylococcus aureus and its food poisoning toxins: characterization and outbreak investigation. FEMS Microbiol. Rev. 36, 815-836.

22. HRN EN ISO 6888-1:2004, Microbiology of food and animal feeding stuffs -- Horizontal method for the enumeration of coagulase-positive staphyloccoco (Staphylococcus aureus and other species) -- Part 1: Technique using Baird-Parker agar medium (ISO 6888-1:1999+Amd 1:2003; EN ISO 68881:1999+A1:2003)

23. HRN EN ISO 19020:2017, Microbiology of the food chain -- Horizontal method for the immunoenzymatic detection of staphylococcal enterotoxins in foodstuffs (ISO 19020:2017; EN ISO 19020:2017)

24. HUNT, K., J. SCHELIN, P. RÅDSTRÖM, F. BUTLER and K. JORDAN (2012): Classical enterotoxins of coagulase-positive Staphylococcus aureus isolates from raw milk and raw milk cheese production in Ireland. Dairy Sci. Technol. 92, 487-499.

25. JØRGENSEN, H. J., T. MØRK, H. R. HØGÅSEN and L. M. RØRVIK (2005): Enterotoxigenic Staphylococcus aureus in bulk milk in Norway. J. Appl. Microbiol. 99, 158-166.

26. KADARIYA, J., T. C. SMITH and D. THAPALIYA (2014): Staphylococcus aureus and staphylococcal food-borne disease: an ongoing challenge in public health. BioMed Res. Int. 2014, 827965.

27. KATSUDA, K., E. HATA, H. KOBAYASHI, M. KOHMOTO, K. KAWASHIMA, H. TSUNEMITSU and M. EGUCHI (2005): Molecular typing of Staphylococcus aureus isolated from bovine mastitic milk on the basis of toxin genes and coagulase gene polymorphisms. Vet. Microbiol. 105, 301-305.

28. KÉROUANTON, A., J.-A. HENNEKINNE, C. LETERTRE, L. PETIT, O. CHESNEAU, A. BRISABOIS and M. L. DE BUYSER, (2007): Characterization of Staphylococcus aureus strains associated with food poisoning outbreaks in France. Int. J. Food Microbiol. 115, 369-375.

29. KLUYTMANS, J., A. VAN BELKUM and $H$. VERBRUGH (1997): Nasal carriage of Staphylococcus aureus: epidemiology, underlying mechanisms, and associated risks. Clin. Microbiol. Rev. 10, 505-520.

30. LANDEKA, V., M. ALJIČEVIĆ, A. SESAR and L. KOZAČINSKI (2019): Microbiological quality of fresh cow's milk cheese sold at Sarajevo and Zagreb farmers' markets. Vet. stn. 50, 435-443.

31. LE LOIR, Y., F. BARON and M. GAUTIER (2003): Staphylococcus aureus and food poisoning. Genet. Mol. Res. 2, 63-76.

32. LITTLE, C. L., J. R. RHOADES, S. K., SAGOO, J. HARRIS, M. GREENWOOD, V. MITHANI, K. GRANT and J. MCLAUCHLIN (2008): Microbiological quality of retail cheeses made from raw, thermized or pasteurized milk in UK. Food Microbiol. 25, 304-312.

33. LONCAREVIC, S., H. J. JØRGENSEN, A. LØVSETH, T. MATHISEN and L. M. RØRVIK (2005): Diversity of Staphylococcus aureus enterotoxin types within single samples of raw milk and raw milk products. J. Appl. Microbiol. 98, 344-350.

34. LJEVAKOVIĆ-MUSLADIN, I., M. LAKIĆ i A. DŽONO-BOBAN (2014): Mikrobiološka ispravnost sireva s dubrovačkih tržnica. $3^{\text {rd }}$ Croatian Congress of Preventive Medicine and Health Promotion, Vinkovci, 09-12.10.2014.

35. LJEVAKOVIĆ-MUSLADIN, I., M. LAKIĆ, S. LEVAK and L. KOZAČINSKI (2016): Microbiological quality of domestic cheese in Dubrovnik Croatia region, Zbornik prednášok a posterov. Bezpečnost' a kvalita mliečnych a rastlinnýh komodít / Maĺa, P. (ur.). Košice: University of Veterinary Medicine and Pharmacy in Košice Department of Food Hygiene and Technology, 228-233.

36. MARKOV, K., J. FRECE, D. ČVEK and F. DELAŠ (2009): Listeria monocytogenes and other contaminants in fresh cheese and cream from Zagreb city area domestic production. Mljekarstvo 59, 225-231 (in Croatian).

37. MITCHELL, D. T., D. G. LEVITT, P. M. SCHLIEVERT and D. H. OHLENDORF (2000): Structural evidence for the evolution of pyrogenic toxin superantigens. J. Mol. Evol. 51, 520-531.

38. MORANDI, S., M. BRASCA, C. ANDRIGHETTO, A. LOMBARDI and R. LODI (2009): Phenotypic and Genotypic Characterization of Staphylococcus aureus Strains from Italian Dairy Products. Int. J. Food Microbiol. 2009, 501362.

39. NORMANNO, G., G. LA SALANDRA, A. DAMBROSIO, N. C. QUAGLIA, M. CORRENTE, A. PARISI, G. SANTAGADA, A. FIRINU, E. CRISETTI and G. V. CELANO (2007a): Occurrence, characterization and antimicrobial resistance of enterotoxigenic Staphylococcus aureus isolated from meat and dairy products. Int. J. Food Microbiol. 115, 290-296.

40. NORMANNO, G., G. CORRENTE, G. LA SALANDRA, A. DAMBROSIO, N. C., QUAGLIA, A. PARISI, G. GRECO, A. L. BELLACICCO, S. VIRGILIO and G. V. CELANO (2007b): Methicillinresistant Staphylococcus aureus (MRSA) in foods of animal origin product in Italy. Int. J. Food Microbiol. 117, 219-222.

41. O'BRIEN, M., K. HUNT, S. MCSWEENEY and K. JORDAN (2009): Occurrence of foodborne pathogens in Irish farmhouse cheese. Food Microbiol. 26, 910-914.

42. PATEL, J. B., R. J. GORWITZ and J. A. JERNIGAN (2009): Mupirocin resistance. Clin. Infect. Dis. 49, 935-941.

43. PELISSER, M. R., C. S. KLEIN, K. R. ASCOLI, T. R. ZOTTI and A. C. M. ARISIL (2009): Occurrence of Staphylococcus aureus and multiplex PCR detection of classical enterotoxin genes in cheese and meat products. Braz. J. Microbiol. 40, 145-148.

44. ROLA, J. G., A. CZUBKOWSKA, W. KORPYSADZIRBA and J. OSEK (2016): Occurrence of Staphylococcus aureus on Farms with Small Scale 
Occurrence, enterotoxin production and antimicrobic susceptibility of Staphylococcus aureus isolates from domestic cheeses in the Dubrovnik area

Pojavnost, stvaranje enterotoksina i antimikrobna osjetljivost izolata Staphylococcus aureus izoliranih iz domaćih svježih sireva s područja grada Dubrovnika

Production of Raw Milk Cheeses in Poland. Toxins 8, 62.

45. ROSEC, J. P., J. P. GUIRAUD, C. DALET and N. RICHARD (1997): Enterotoxin production by staphylococci isolated from foods in France. Int. J. Food Microbiol. 35, 213-221.

46. ROSENGREN, A., A. FABRICIUS, B. GUSS, S. SYLVÉN and R. LINDQUIST (2010): Occurrence of foodborne pathogens and characterization of Staphylococcus aureus in cheese produced on farmdairies. Food Microbiol. 144, 263-269.

47. SAMARŽIJA, D., S. DAMJANOVIĆ and T. POGAČIĆ (2007): Staphylococcus aureus u siru. Mljekarstvo 57, 31-48.

48. STEPHAN, R., C. ANNEMÜLLER, A. A. HASSAN and CH. LÄMMLER (2001): Characterization of enterotoxigenic Staphylococcus aureus strains isolated from bovine mastitis in north-east Switzerland. Vet. Microbiol. 78, 373-382.

49. TAMARAPU, S., J. L. MCKILLIP and M. DRAKE (2001): Development of a multiplex polymerase chain reaction assay for detection and differentiation of Staphylococcus aureus in dairy products. J. Food Prot. 64, 664-668.

50. WERTHEIM, H. F., D. C. MELLES, M. C. VOS, VAN W. LEEUWEN, A. VAN BELKUM, H. A. VERBRUGH and J. L. NOUWEN (2005): The role of nasal carriage in Staphylococcus aureus infections. Lancet Infect. Dis. 5, 751-762.

51. WIENEKE, A. A., D. ROBERTS and R. J. GILBERT (1993): Staphylococcal food poisoning in the United Kingdom, 1969-1990. Epidemiol. Infect. 110, 519-531.

52. WILLIAMS, A. G. and S. E. WITHERS (2010): Microbiological characterisation of artisanal farm house cheeses manufactured in Scotland. Int. J. Dairy Technol. 63, 356-369.

53. ZDOLEC, N., V. DOBRANIĆ, I. BUTKOVIĆ, A. KOTURIĆ, I. FILIPOVIĆ and V. MEDVID (2016): Antimicrobial susceptibility of milk bacteria from healthy and antimicrobial susceptibility of milk bacteria from healthy and drug-treated cow udder rug-treated cow udder. Vet. arhiv 86, 163-172.

\section{Pojavnost, stvaranje enterotoksina i antimikrobna osjetljivost izolata Staphylococcus aureus izoliranih iz domaćih svježih sireva s područja grada Dubrovnika}

Ivana LJEVAKOVIĆ-MUSLADIN, dipl. ing. kemije., specijalistica analitike i mikrobiologije namirnica, Marina VODNICA-MARTUCCI, dr. med., specijalistica medicinske mikrobiologije s parazitologijom, Marija KRILANOVIĆ, dr. med., specijalistica kliničke mikrobiologije, Zavod za javno zdravstvo Dubrovnik, Dubrovnik, Hrvatska; dr. sc. Lidija KOZAČINSKI, dr. med. vet., redovita profesorica, Veterinarski fakultet Sveučilišta u Zagrebu, Zagreb, Hrvatska

Staphylococcus aureus je poznati oportunistički patogen, koji uzrokuje široki spektar akutnih i kroničnih bolesti u ljudi i životinja. Stafilokokno trovanje je samo jedna od mnogih bolesti koje uzrokuje ova bakterija. Uzročnici trovanja su enterotoksini koje tijekom rasta $\mathrm{u}$ povoljnim uvjetima $\mathrm{u}$ hrani proizvode enterotoksigeni sojevi $S$. aureus. Epidemiološki podatci pokazuju da se $S$. aureus vrlo često nalazi u sirevima od sirovog mlijeka te su sirevi posljedično često upleteni u stafilokokna trovanja. Budući da nema podataka o prirodi $S$. aureus izoliranog iz sireva proizvedenih u Hrvatskoj, cilj je ovog istraživanja bio odrediti pojavnost, sposobnost stvaranja enterotoksina i antimikrobnu osjetljivost izolata $S$. aureus iz domaćih svježih sireva proizvedenih na području grada Dubrovnika. Od 30 ispitanih uzoraka sireva $18(60 \%)$ je bilo visoko zagađeno sojevima S. aureus. Razina zagađenja je bila u rasponu od 3,94 do $6,26 \log _{10} \mathrm{cfu} / \mathrm{g}$, a dodatno je tijekom prodaje na tržnicama bila podržana neodgovarajućim temperaturnim režimom iznad $8{ }^{\circ} \mathrm{C}$. Iako su bili visoko zagađeni, stafilokokni enterotoksini nisu nađeni niti u jednom uzorku. Ukupno je prikupljeno 180 koagulaza-pozitivnih izolata iz 18 uzoraka sireva, od čega je 175 izolata potvrđeno lateks aglutinacijskim testom kao S. aureus. Sposobnost stvaranja enterotoksina je detektirana kod 35 (20\%) izolata, a 32 izolata su proizvodila enterotoksin C. Za ostala tri izolata se pretpostavlja da proizvode enterotoksin E. Antimikrobna rezistencija je utvrđena kod 1,1\% izolata i to jedino na mupirocin. Međutim, cjelovit sveobuhvatan zaključak o prirodi izolata $S$. aureus ne može se donijeti bez određivanja genotipskih karakteristika prisutnosti gena za enterotoksine i molekularne tipizacije s ciljem određivanja podrijetla izolata.

Ključne riječi: Staphylococcus aureus, sir, stafilokokni enterotoksini, antimikrobna osjetljivost 